\title{
Member Participation And Managerial Capabilities Of Managers Implication On The Development Of Sharia-Based Cooperative Business
}

\author{
Harkit Rahmawati* \\ Dosen Prodi Perbankan Syariah STIES Indonesia Purwakarta \\ Jl. Veteran No. 150-152 Ciseureuh Purwakarta 41118 Jawa Barat Indonesia \\ harkitrahmawati@gmail.com
}

\begin{abstract}
The number of cooperative corporations that experienced business failure, in 2014 as many as 72,230 cooperatives or about $35 \%$ of the total 260 thousand cooperatives went bankrupt. A different phenomenon emerged in Sharia-based financial institutions, since it was first introduced in 1990, there are only a few dozen units, and at present the number in Indonesia is over 5,500. According to Ropke 'the success of a Cooperative is influenced by internal factors (Managers (Managers and managers), Service, Member Participation, and Capital) and external factors (Business climate (competition) and Government policy and technological developments). This research is conducted to know the extent of implication or influence of member participation and managerial capability of management toward syariah based business development. The method are used is descriptive analytic with Quantitative approach, The type of data in this study is the primary data sourced from the Board and Members of Sharia cooperatives in Purwakarta district. Data collection techniques conducted are interviews to administrators and observation data cooperatives development in terms of Capital, the number of Members, turnover, the rest of the business results (earnings) from the year 2010-2016. The results showed that member participation has a positive effect on the development of Sharia-based cooperatives with a significance level of $74.6 \%$, While Managerial Ability has positive effect to Cooperative development equal to 56,3\%. Simultaneously Member participation, and managerial ability have positive effect on Cooperative development equal to $57,67 \%$.
\end{abstract}

Keywords - Sharia Cooperatives, participation, members, Managerial Capabilities, business developmen.

\section{PENDAhuluan}

Krisis financial global yang terjadi pada tahun 2008-2009 lalu memiliki dampak negatif terhadap usaha sektor riil di Indonesia, utamanya terhadap kaum akar rumput yang menyebabkan banyaknya pengusaha yang "gulung tikar" dan mengalami kebangkrutan. Permasalahan permodalan yang kerap kali dihadapi oleh pengusaha mikro dan kecil, karena pada umumnya mereka merupakan usaha yang tidak bankable.

Dalam kenyataannya operasional perbankan konvensional maupun syariah belum dapat menjangkau sektor usaha mikro ditingkat akar rumput (grass root).hal ini dikarenakan dunia perbankan sebagai lembaga intermediasi keuangan yang dalam menjalankan fungsinya menyalurkan pembiayaan kepada masyarakat masih mensyaratkan jaminan yang tidak mudah dipenuhi oleh nasabah, khususnya nasabah kecil. di sisi lain keberadaan perbankan secara operasional terbatas hanya di kota-kota, sedangkan para pelaku usaha mikro dan kecil sebagian besar berada di desa-desa. Dengan demikian perbankan konvensional maupun syariah belum mampu secara optimal memberikan layanan dan menjangkau usaha sektor riil dengan optimal.

Kondisi tersebut melatarbelakangi munculnya lembagalembaga keuangan mikro yang mampu menjangkau hingga ke pedesaan-pedesaan dengan berbagai bentuk seperti Koperasi simpan pinjam, koperasi kredit, hingga Koperasi yang berbasis syariah. Keberadaan koperasi memang sudah lama di Indonesia, akan tetapi keberadaan koperasi konvensional setiap tahun mengalami penurunan jumlah. Seperti data yang dipublikasikan kementrian koperasi republik Indonesia pada tahun 2014-2016.
Grafik 1.1. Jumlah koperasi berbadan Hukum yang "Gulung Tikar"

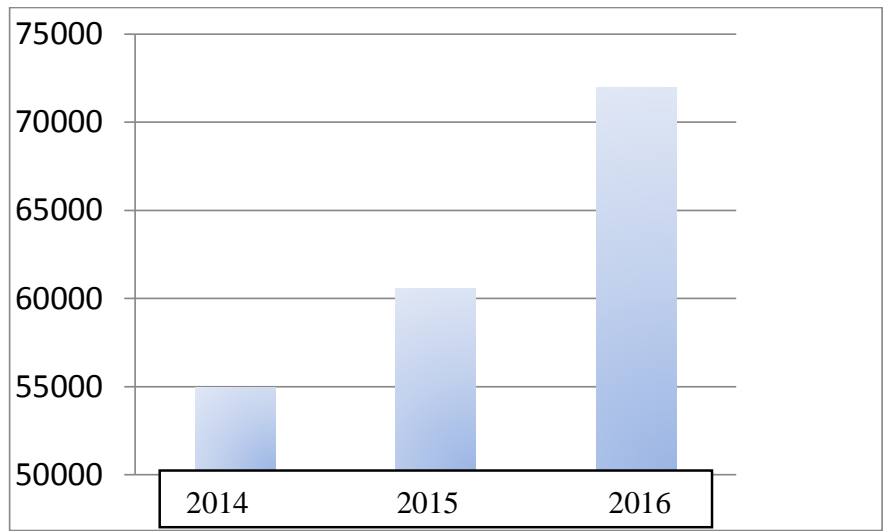

Sumber: Kementrian Koperasi dan UMKM RI (data diolah)

Jumlah koperasi berbadan hukum yang mengalami kegagalan beroperasi (bangkrut) dari tahun 2014 hingga 2016 secara signifikan mengalami peningkatan. Pada tahun 2014 sebanyak 54.974 koperasi atau sekitar $28,29 \%$ dari total jumlah 194.295 koperasi. Pada tahun 2014 sebanyak 60.584 koperasi atau sekitar $29,74 \%$ dari jumlah 203.701 koperasi, sedangkan pada tahun 2015 sebanyak 72.230 koperasi atau sekitar 35\% dari total 260 ribu koperasi mengalami kebangkrutan.

Perkembangan koperasi syariah di indonesia sampai saat ini telah mencapai jumlah jaringan yang tersebar di seluruh Indonesia dan tampil sebagai pendorong intermediasi usaha kecil (mikro). Perkembangan ini dibuktikan dengan jumlah koperasi syariah yang dikembangkan sampai kepelosok indonesia dengan jumlah anggota mencapai 2.694 .013 orang 
dan jumlah asset mencapai rp. 4,7 triliun $^{1}$ pada tahun 2015. Sejak pertama kali koperasi koperasi syariah pada tahun 1990 diperkenalkan, hanya ada beberapa puluh unit saja, dan pada saat ini jumlah koperasi syariah di Indonesia sudah lebih dari $5.500^{2}$.

Tabel 1.1 perkembangan Jumlah anggota, Omset dan SHU KOPERASI SYARIAH Se-Kabupaten Bandung Barat tahun

\begin{tabular}{|c|c|c|c|c|c|c|c|}
\hline No & Tahun & $\begin{array}{c}\text { Jumlah } \\
\text { Anggota }\end{array}$ & $\%$ & $\begin{array}{c}\text { Omset } \\
\text { (Juta } \\
\text { Rupiah) }\end{array}$ & $\%$ & $\begin{array}{c}\text { SHU } \\
\text { (Juta } \\
\text { Rupiah) }\end{array}$ & $\%$ \\
\hline 1 & 2012 & 1740 & - & 4,377 & - & 2,288 & - \\
\hline 2 & 2013 & 1893 & 0.08 & 6,960 & 0.37 & 4,480 & 0.49 \\
\hline 3 & 2014 & 2389 & 0.21 & 9,086 & 0.23 & 5,543 & 0.19 \\
\hline 4 & 2015 & 3019 & 0.21 & 188,879 & 0.95 & 88,439 & 0.94 \\
\hline 5 & 2016 & 3320 & 0.09 & 211,353 & 0.11 & 101,105 & 0.13 \\
\hline
\end{tabular}

Dari data di atas dapat terlihat bahwa koperasi syariah yang berada di kawasan kabupaten bandung barat mulai tahun 2012 sampai dengan tahun 2016 mengalami perkembangan dari setiap tahunnya. Fenomena yang menarik terjadi pada salah satu koperasi syariah yang berada di kawasan bandung barat tepatnya di desa cihanjuang kecamatan parongpong yaitu koperasi syariah el dana manfaat. Perkembangan koperasi syariah yang lahir pada tahun 2010 ini sangat pesat dilihat dari pertumbuhan Aset, Omzet, Laba Usaha (SHU) dan Jumlah Keanggotaannya.

Tabel 1.2 perkembangan Jumlah anggota, Omset dan SHU KOPERASI SYARIAH EL DANA MANFAAT

\begin{tabular}{|c|c|c|c|c|c|c|c|}
\hline No & Tahun & $\begin{array}{c}\text { Jumlah } \\
\text { Anggota }\end{array}$ & $\%$ & $\begin{array}{c}\text { Omset } \\
\text { (Juta Rupiah) }\end{array}$ & $\%$ & $\begin{array}{c}\text { SHU } \\
\text { (Juta Rupiah) }\end{array}$ & $\%$ \\
\hline 1 & 2011 & 106 & - & 35,822 & - & 1,193 & - \\
\hline 2 & 2012 & 145 & 12 & 83,493 & 112 & 3,264 & 149 \\
\hline 3 & 2013 & 166 & 115 & 174,853 & 109 & 28,965 & 900 \\
\hline 4 & 2014 & 412 & 119 & 357,886 & 121 & 60,976 & 102 \\
\hline 5 & 2015 & 1045 & 124 & 778,437 & 120 & 131,866 & 115 \\
\hline 6 & 2016 & 2056 & 106 & $1,156,789$ & 52 & 202,786 & 80 \\
\hline
\end{tabular}

Dari data di atas dapat terlihat bahwa koperasi syariah el dana manfaat yang berada di kawasan kabupaten Bandung Barat mulai tahun 2011 sampai dengan tahun 2016 mengalami perkembangan positif dari setiap tahunnya, bisa di lihat perkembangan itu dari sisi keanggotaannya yang mengakibatkan terhadap perkembangan dari omset setiap koperasi syariah pada tiap tahunnya mengalami perkembangan dan pada posisi laba (sisa hasil usaha) pun meningkat setiap tahun. Perkembangan cukup signifikan dapat terlihat bahwa perkembangan yang tinggi terjadi selalu diatas $100 \%$.

Dengan adanya jumlah peningkatan secara signifikan tersebut menjadi salah satu indikasi berkembangnya koperasi syariah di wilayah bandung barat secara positif, koperasi syariah berkembang merupakan tujuan yang diinginkan oleh seluruh anggota dan pelaku kegiatan koperasi syariah.

\section{METODOLOGI}

Metode penelitian yang digunakan adalah deskriptif analitik, Sugiyono berpendapat bahwa "Metode penelitian deskriptif adalah metode yang digunakan untuk mencari unsur-unsur, ciri-ciri, sifat-sifat suatu fenomena. Metode desktiptif dalam pelaksanaannya dilakukan melalui teknik survey, studi kasus, studi komparatif, studi tentang waktu dan gerak, analisis tingkah laku, dan analisis dokumenter. Metode deskriptif ini dimulai dengan mengumpulkan data, mengklasifikasi data, menganalisis data dan menginterpretasikannya".

Adapun ciri-ciri dari metode penelitian deskriptif analitik adalah tidak hanya memberikan gambaran saja terhadap suatu fenomena tetapi juga menerangkan hubungan-hubungan, menguji hipotesa-hipotesa, membuat prediksi serta mandapatkan makna dan implikasi dari suatu permasalahan yang ingin dipecahkan.

Populasi merupakan keseluruhan dari subjek penelitian. Suharsimi Arikunto mengemukakan bahwa "populasi adalah keseluruhan objek penelitian atau totalitas kelompok subjek, baik manusia, gejala, nilai, benda-benda atau peristiwa yang menjadi sumber data untuk suatu penelitian". Berdasarkan definisi diatas, maka populasi merupakan keseluruhan dari objek yang akan diteliti. Adapun yang menjadi populasi dalam penelitian ini adalah seluruh Koperasi yang sudah memiliki badan hukum koperasi di Kabupaten Bandung Barat.

Sampel menurut Sugiono sampel adalah sebagian dari jumlah dan karakteristik yang dimiliki populasi. Dengan kata lain sampel adalah sebagian anggota populasi yang dipilih dengan menggunakan prosedur tertentu sehingga diharapkan dapat mewakili populasinya. Dalam hal ini sampel yang diambil dalam penelitian menggunakan random sampling sampel jenuh karena populasi pengurus kurang dari 30 sehingga untuk sampel diambil secara keseluruhan. Sehingga yang menjadi sampel pada penelitian ini adalah seluruh pengurus Koperasi Syariah El Dana Manfaat.

\section{PEMBAHASAN}

Koperasi syariah yang pada umumnya berbadan hukum koperasi jasa keuangan syariah ini merupakan suatu lembaga yang diadopsi dari sistem koperasi, dan perbedaannya terletak dari prinsip operasionalnya yang berbasis kepada syariah dengan meniadakan sistem bunga. Oleh karena itu keberhasilan koperasi syariah dalam operasional usahanya didorong dari beberapa faktor.

Menurut alfred hanel keberhasilan koperasi (juga koperasi syariah) dapat terlihat dari tiga komponen yaitu sebagai berikut :

\section{Business Succes}

Yaitu keberhasilan dari suatu Koperasi yang dapat dilihat dari usaha Koperasi itu sendiri seperti sejauh mana Koperasi dikelola secara efisien dalam rangka mencapai tujuan-tujuan sebagai suatu lembaga (ekonomi usaha) yang mandiri.

2. Member Succes

Efisiensi yang berorientasi pada anggota, yaitu pelayanan yang bersifat menunjang anggota, yaitu pelayanan yang bersifat menunjang dari perusahaan Koperasi, dalam hal ini kepentingan dan tujuan para anggota.

\section{Development Succes}

Berkaitan dengan dampak secara langsung atau tidak langsung yang ditimbulkan oleh usaha Koperasi sehingga kontribusi Koperasi terhadap pencapaian tujuan-tujuan pembangunan pemerintah.

Menurut Ropke keberhasilan sebuah Koperasi dipengaruhi oleh:

1. Faktor internal yang terdiri dari :
a. Pengelola (Pengurus dan manajer)
b. Pelayanan
c. Partisipasi anggota 


\section{d. Permodalan}

2. Faktor eksternal yang terdiri dari :

a. Iklim usaha (persaingan)

b. Kebijakan pemerintah dan perkembangan teknologi.

Dari teori menurut Menurut Bernhard Limbong tingkat keberhasilan Koperasi dilihat dari tiga faktor utama 1) partisipasi anggota, partisipasi anggota adalah pelaksanaan kewajiban dan hak sebagai anggota. Kewajiban anggota adalah penyetoran simpanan pokok, simpanan wajib, dan atau simpanan dari sisa hasil usaha (SHU) sebagai modal kerja. Sedangkan pemanfaatan jasa pelayanan adalah hak sekaligus kewajiban. 2) Profesionalisme manajemen, manajemen disini menyangkut perencanaan bisnis, pengawasan dan pengendalian, hingga evaluasi dan pengendalian keuangan. Mutu manajemen Koperasi sangat ditentukan oleh kapasitas organisasi dan leadership Koperasi, mutu tenaga profesional, ketepatan memilih strategi bisnis, penetrasi pasar, jaringan yang dibangun, pemanfaatan IPTEK, serta riset dan informasi. 3) Faktor yang berasal dari luar, faktor dari luar yang berpengaruh adalah peraturan perundang-undangan dan peraturan pemerintah atau kebijakan pemerintah terkait kebijakan dibidang ekonomi. Seperti UU penanaman modal, UU persaingan usaha, UU pajak, UU perbankan, dan lain-lain.

Pengurus sebagai pengelola Koperasi Koperasi Syariah harus mampu memberikan dorongan agar dapat menarik anggota untuk ikut serta dalam pengembangan Koperasi Koperasi Syariah. Untuk menarik minat seseorang agar menjadi anggota Koperasi Koperasi Syariah upaya yang dapat dilakukan adalah dengan memberikan pelayanan yang baik bagi anggota pada khususnya dan masyarakat pada umumnya dalam segala bidang. Semua hal tersebut akan dapat baik dengan adanya prestasi dan hasil kerja yang baik dari pengurus, dan partisipasi anggota.

Dengan kata lain "motor" penggerak bagi usaha Koperasi Syariah adalah ditangan pengurus. Sehingga dibutuhkan orangorang yang mempunyai latar belakang pengetahuan yang luas dalam bidang Koperasi dan dalam hal kemasyarakatan. Kemampuan manajerial pengurus diukur dari proses mempengaruhi, pengambilan keputusan, komunikasi, dan inovatif.

Berdasarkan fakta dan data di atas, penulis tertarik untuk meneliti masalah yang terkait dengan perkembangan profitabilitas Koperasi Syariah dengan tingkat perkembangan reatif tinggi diatas $100 \%$. Jadi judul penelitian yang ingin penulis angkat yaitu mengenai "Pengaruh Partisipasi Anggota Dan Manajerial Pengurus Terhadap Perkembangan Koperasi Syariah El Dana Manfaat Kecamatan Parongpong Kabupaten Bandung Barat.

\section{A. Hasil Dan Pembahasan}

Tabel 1.3

Data Hasil Penelitian Variabel Partisipasi Anggota Koperasi Syariah El Dana Manfaat

\begin{tabular}{|c|c|}
\hline Tahun & Jumlah simpanan \\
\hline 2010 & 172.356 .804 \\
\hline 2011 & 332.356 .804 \\
\hline 2012 & 482.356 .804 \\
\hline 2013 & 829.946 .165 \\
\hline 2014 & 1.017 .090 .889 \\
\hline Sumber: Hasil Pemyebaran Angket, diolah & 1.196 .577 .516 \\
\hline
\end{tabular}

Sesuai dengan data pada tabel diatas dapat terlihat bahwa partisipasi anggota koperasi syariah El Dana Manfaat setiap tahunnya mengalami peningkatan menyimpan secara signifikan.

\section{B. Gambaran Umum Kemampuan Manajerial Pengurus}

Pengurus merupakan sebagai roda pengerak didalam koperasi syariah mengingatkan pengurus memiliki peran yang sangat penting sehingga para pengurus koperasi syariahini harus memiliki kemampuan untuk menggerakan segala sesuatu yang menjadi sumber daya koperasi syariahtersebut baik sumber daya manusia seperti anggota ataupun fasilitas yang telah dimiliki oleh koperasi syariah tersebut. Dengan kata lain dapat diartikan sebagai kemampuan seseorang dalam melaksanakan fungsi manajemen yang meliputi kemapuan perencanaan, pengorganisasian, penggerakan, dan pengawasan. Oleh karena itu para pengurus harus mampu membekali diri dengan ilmu-ilmu pengetahuan dan keterampilan manajemen yang sesuai, kemampuan yang telah dimiliki itu lalu diintegrasikan dalam sebuah koperasi syariah dalam pengambilan keputusan yang efektif.

Sesuai dengan hasil dari pengolahan data mengenai variable kemampuan manajerial pengurus dari para pengurus koperasi syariah, dapat diklasifikasikan sebagai berikut :

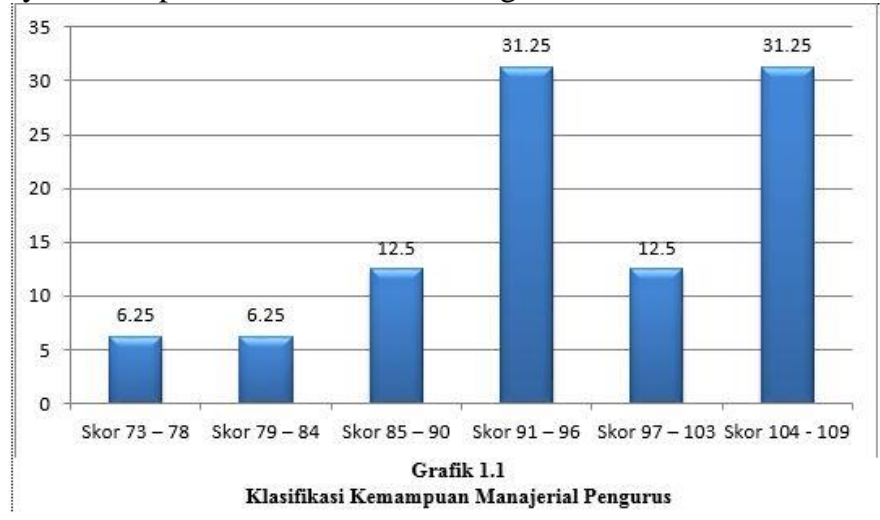

Berdasarkan tabel dan grafik diatas, dapat terlihat bahwa kemampuan manajerial pengurus pada koperasi syariah dilihat dari perencanaan, pengorganisasian, penggerakan, pengawasan, dan pengambilan keputusan jika dalam menjalankan roda koperasi syariah nya sesuai dengan perencanaan manajemen berada pada kriteria sangat tinggi sekali sebanyak 5 responden pengurus yaitu sebesar $31.25 \%$, kriteria kemampuan manajerial pengurus selanjutnya pada kriteria sangat tinggi sebanyak 2 orang pengurus atau sebesar $12.5 \%$, untuk kriteria tinggi diperoleh dari 5 pengurus koperasi syariah yaitu sebesar $31.25 \%$, untuk kriteria sedang dengan sebanyak 2 pengurus atau sebesar $12.5 \%$ dan kriteria rendah dan sangat rendah sebanyak 2 pengurus atau sebesar $6.25 \%$.

\section{Pengaruh Partisipasi Anggota dan Kemampuan Manajerial Pengurus Terhadap Perkembangan Koperasi Syariah}

Berdasarkan pengolahan data menggunakan SPSS 16, maka dapat diperoleh gambaran mengenai pengaruh partisipasi anggota dan kemampuan manajerial pengurus terhadap perkembangan koperasi syariah. Model persamaan regresinya adalah sebagai berikut : 


\begin{tabular}{|c|c|c|c|c|c|}
\hline \multicolumn{6}{|c|}{$\begin{array}{c}\text { Tabel } 1.4 \\
\text { Coefficients }^{\mathrm{a}}\end{array}$} \\
\hline & \multirow{2}{*}{ Model } & \multicolumn{2}{|c|}{$\begin{array}{l}\text { Unstandardized } \\
\text { Coefficients }\end{array}$} & \multirow{2}{*}{$\begin{array}{c}\begin{array}{c}\text { Standardized } \\
\text { Coefficients }\end{array} \\
\text { Beta } \\
\end{array}$} & \multirow[t]{2}{*}{ T } \\
\hline & & B & Std. Error & & \\
\hline 1 & (Constant) & 2.364 & 2.247 & & 1.052 \\
\hline & LN Partisipasi Anggota & 0.499 & 0.108 & 0.634 & 4.608 \\
\hline & LN Manajerial Pengurus & 1.860 & 0.652 & 0.393 & 2.855 \\
\hline
\end{tabular}

Sumber: Lampiran 008

Dapat dilihat hasil dari pengolahan analisis data menggunakan SPSS 16 yang dapat terlihat pada tabel di atas, dapat disimpulkan bahwa persamaan linear pada perkembangan KOPERASI SYARIAH adalah sebagai berikut : $\hat{Y}$ $\mathrm{Se}$ $=2.364+0.499 \mathrm{X} 1+1.860 \mathrm{X} 2$

$\begin{array}{llll}\mathrm{Se} & =(2.247) & (0.108) & (0.652)\end{array}$ $\mathrm{t}$ Hitung $\quad=(1.052)$

Dimana

LNY = Perkembangan koperasi syariah

LNX1 = Partisipasi Anggota

LNX2 = Manajerial Pengurus

Dari persamaan diatas dapat diuraikan sebagai berikut :

1. Jika partisipasi anggota (X1) dan manajerial pengurus (X2) nol maka perkembangan koperasi syariah (modal, SHU, omset) (Y) sebesar Rp. 828.317.669.5.

2. Koefisien regresi X1 adalah 0.499 , hal ini menunjukan bahwa setiap peningkatan variabel partisipasi anggota anggota (menyimpan: tabungan idul fitri, tabungan idul adha, dan tabungan pendidikan. Meminjam: usaha dan konsumsi) sebesar satu rupiah akan meningkatkan perkembangan koperasi syariah (modal, SHU, omset) sebesar $0.49 \%$ dengan asumsi variabel yang lainnya adalah konstan.

3. Koefisien regresi X2 adalah 1.860 , hal ini menunjukan bahwa setiap peningkatan variabel manajerial pengurus sebesar satu satuan akan meningkatkan perkembangan koperasi syariah sebesar 1.860 satu-satuan dengan asumsi variabel yang lainnya konstan.

\section{Uji Parsial (Uji t)}

Uji t ini dilakukan untuk mengetahui seberapa besar tingkat signifikan secara statistik dari pengaruh masing-masing variabel bebas terhadap variabel terikat. Pengujian melalui uji t ini, penulis menggunakan tingkat kesalahan sebesar 5\% atau sebesar 0.05 untuk taraf signifikansi sebesar $95 \%$ dengan $\mathrm{df}=$ $\mathrm{n}-\mathrm{k}(16-3)=13$. Dengan $\mathrm{df}=13$ dan alpha $5 \%$ maka diperoleh t tabel sebesar 2.160 Untuk hasil uji t masing-masing variabel bebas adalah sebagai berikut :

$$
\text { Tabel } 1.5
$$

Uji Hipotesis Signifikan (Uji t) Partisipasi Anggota dan Manajerial Pengurus Terhadap Perkembangan KOPERASI SYARIAH

\begin{tabular}{|c|c|c|c|c|c|c|c|}
\hline \multicolumn{8}{c}{ Perkembangan KOPERASI SYARIAH } \\
\hline Variabel & thitung & & tabel & Sign & $\begin{array}{c}\text { Taraf } \\
\text { Sign }\end{array}$ & Keputusan & Kesimpulan \\
\hline LNX1 & 4.608 & $>$ & 2.160 & 0.000 & 0.05 & Ho ditolak & Signifikan \\
\hline LNX2 & 2.855 & $>$ & 2.160 & 0.014 & 0.05 & Ho ditolak & Signifikan \\
\hline Sumber : lampiran 008 & & & & &
\end{tabular}

Berdasarkan hasil uji t pada tabel diatas diketahui untuk ttabel sebesar 2.160 dengan demikian :

1. Nilai thitung untuk X1 sebesar $4.608>$ ttabel sebesar 2.160 maka menolak H0 dan menerima Ha, artinya bahwa partisipasi anggota berpengaruh positif terhadap perkembangan KOPERASI SYARIAH.

2. Nilai thitung untuk $X 2$ sebesar $2.855>$ ttabel sebesar 2.160, maka menolak H0 dan menerima Ha, artinya bahwa manajerial pengurus berpengaruh positif terhadap perkembangan KOPERASI SYARIAH.

\section{E. Uji Simultan (Uji F)}

Untuk menguji pengaruh simultan variabel bebas terhadap variabel terikat dilakukan melalui uji F. Dapat diketahu bahwa Fhitung dan tingkat signifikansi dapat dilihat pada tabel 4.39 berikut :

\begin{tabular}{|c|c|c|c|c|c|c|c|}
\hline \multicolumn{8}{|c|}{$\begin{array}{c}\text { Tabel } 1.6 \\
\text { Hasil Uji Simultan Partisipasi Anggota dan Kemampuan Manajerial Pengurus Terhadap } \\
\text { Perkembangan KOPERASI SYARIAH }\end{array}$} \\
\hline Model & F hitung & & F tabel & Prob & Alpha & Keputusan & Kesimpulan \\
\hline 1 & 30.521 & $>$ & 8.74 & 0.000 & 0.05 & Menolak Ho & $\begin{array}{l}\text { Berpengaruh secara } \\
\text { simultan }\end{array}$ \\
\hline
\end{tabular}

Dari tabel hasil uji simultan tabel 4.39 untuk mencari $\mathrm{F}$ tabel $(\mathrm{Fc} \mathrm{a}, \mathrm{k}-1, \mathrm{n}-\mathrm{k})$ dengan alpha $=0.05,(\mathrm{k}-1)=3-1=2,(\mathrm{n}-\mathrm{k})=$ $16-3=13$ sehingga diperoleh sebesar 3.81dan perolehan untuk Fhitung sebesar $30.521>$ Ftabel 8.74, maka H0 ditolak dan Ha diterima. Yang artinya secara simultan variabel bebas berpengaruh terhadap variabel terikat, dengan demikian partisipasi anggota dan manajerial pengurus berpengaruh terhadap perkembangan Koperasi Syariah.

\section{F. Pengujian Koefisien Determinasi (R2)}

Koefisien Determinasi (R2) adalah angka yang menunjukan besarnya derajat kemampuan dalam menerangkan variabel bebas terhadap variabel terikat. Besarnya nilainya $\mathrm{R} 2$ berada di nol dan satu $(0<\mathrm{R} 2<1)$. Jika hasilnya semakin mendekati satu maka hasil dari model itu baik dan untuk tingkat kedekatan variabel bebas dan variabel terikat pun semakin dekat pula. Berdasarkan hasil estimasi menggunakan program SPSS 16 hasilnya dapat terlihat pada tabel 4.40 berikut :

\begin{tabular}{|c|ccccc|}
\multicolumn{5}{|c|}{ Tabel 1.7 } \\
Hasil Regresi Koefisien Determinasi \\
\hline Model & $\mathrm{R}$ & R Square & $\begin{array}{c}\text { Adjusted R } \\
\text { Square }\end{array}$ & $\begin{array}{c}\text { Std. Error of the } \\
\text { Estimate }\end{array}$ \\
\hline 1 & $0.908^{2}$ & 0.824 & 0.797 & 0.51919 \\
\hline Sumber-Lampiran pengujian SPSS & & & \\
\hline
\end{tabular}

Berdasarkan tabel 4.40 diatas dapat terlihat bahwa $\mathrm{R}$ square (R2) sebesar 0.908 atau 90\%. Sehingga hal ini menunjukan bahwa $90 \%$ perkembangan KOPERASI SYARIAH Y dipengaruhi oleh partisipasi anggota X1 dan Manajerial Pengurus X2. Sedangkan sisanya sebesar $10 \%$ dipengaruhi oleh faktor lain yang berada diluar model penelitian.

\section{KESIMPULAN}

The results showed that member participation has a positive effect on the development of Sharia-based cooperatives with a significance level of $74.6 \%$, While Managerial Ability has positive effect to Cooperative development equal to $56,3 \%$. Simultaneously Member participation, and managerial ability have positive effect on Cooperative development equal to $57,67 \%$

\section{REFERENSI}

[1] Arikunto, Suharsimi. 2010. Prosedur Penelitian (Suatu Pendekatan Praktik). Jakarta: Rineka Cipta.

[2] Budiwati, Neti. 2010. Manajemen Keuangan Koperasi. Bumi Siliwangi Laboratorium Koperasi.

[3] Djazuli. 2002. Lembaga-lembaga Perekonomian Umat. Jakarta: PT. Raja Grafindo Persada.

[4] Djuarni, Wenny. 1999. Pengaruh kualitas pelayanan koperasi dan partisipasianggota terhadap perkebangan saha anggota (sensus pada 


\section{EKSISBANK Vol. 2 No. 2 Desember 2018}

anggota koperasi pengusaha industry kecil suku cadang mesin/KOPISMA Bandung). Tesis UNPAD

[5] Firdaus, Agus. 2004. Perkoperasian: Sejarah, Teori dan Praktek. Jakarta: Ghalia Indonesia.

[6] Gujarati, Damodar,. 2006. Ekonometrika Dasar. Jakarta : Salemba Empat.

[7] Halomoan, Arifin. 2001. Koperasi Teori dan Praktek. Jakarta: Erlangga.

[8] Hanel, Alfred, 1989. Pokok-pokok Pikiran Organisasi Koperasi dan Kebijakan Pengembangan di Negara-negara Berkembang. Bandung: UNPAD.

[9] Hanel, Alfred. 2005. Organisasi Koperasi. Jakarta: Graha Ilmu

[10] Hasan, Amirudin. 1999. Beberapa faktor yang berpengaruh terhadap keberhasilan dan perkembangan koperasi di kotamadya ujung pandang Sulawesi selatan. Tesis UNPAD

[11] Hendar, Kusnadi. 1999. Ekonomi Koperasi. Jakarta : Lembaga Penerbit FE-UI.

[12] Hendar, Kusnandi. 2009. Ekonomi Koperasi, Edisi ke-2. Jakarta: Lembaga Penerbit FE-UI.

[13] Hendrojogi. 2004. Koperasi: Azas-azas, Teori dan Praktek. Jakarta: Rajawali Pers.

[14] Ilmi, Makhalul. 2002. Teori dan Praktek Lembaga Keuangan Syariah. Yogyakarta: UII Pers.

[15] Indrawan, Rully. Pendidikan Koperasi. [online] Tersedia di http://rullyindrawan.wordpress.com/2010/12/08/pendidikan-koperasi/. [7 Februari 2013]

[16] Limbong, Bernhard. 2010. Pengusaha Koperasi: Memperkokoh Pondasi Ekonomi Rakyat. Jakarta: Margaretha Pustaka.

[17] Muhamad. 2010. Politik Islam. Yogyakarta: Pustaka Pelajar.

[18] Muhamad, Ridwan. 2004. Manajemen Koperasi Syariah. Yogyakarta: UII Pers.

[19] Mulyawardani, Sofyan. 2012. Pengaruh Partisipasi Anggota dan Kebijakan Pemerintah terhadap Keberhasilan Koperasi. (Survey pada Koperasi Wanita Anggota PUSKOWAN Jawa Barat). Bandung. Skripsi UPI. Tidak diterbitkan.

[20] Nazir, Moh. 2005. Metode Penelitian. Bogor: Ghalia Indonesia.
[21] Revrisond, Baswir. 2000. Koperasi Indonesia Edisi Pertama Yogyakarta. BPFE.

[22] Riduwan. 2004. Dasar-dasar Statistika. Bandung: Alfabeta.

[23] Ropke, Jochen. 2003. Ekonomi Koperasi, Teori dan Manajemen. Jakarta : Salemba Empat

[24] Rohmana, Yana. 2010. Ekonometrika Teori dan Aplikasi dengan Eviews. Bandung: Laboratorium Pendidikan Ekonomi dan Koperasi FPEB UPI.

[25] Sitio, Arifin. 2001. Koperasi Teori dan Praktek. Jakarta. Erlangga.

[26] Soemitra, Andri. 2009. Bank dan Lembaga Keuangan Syariah. Jakarta: Prenada Media Group.

[27] Sumiyanto, Ahmad. 2008. KOPERASI SYARIAH Menuju Koperasi Modern. Perpustakaan UIN Sunan Kalijati: ISES.

[28] Subandi.2010. Ekonomi Koperasi (Teori dan Praktek). Bandung : Alfabeta

[29] Sudarsono, Edilius. 2005. Koperasi Dalam Teori dan Praktek. Jakarta: Rineka Cipta.

[30] Sudjana.2002. Metoda Statistika. Bandung: Tarsito.

[31] Sudjana. 2005. Metoda Statistika. Bandung: Tarsito

[32] Sugiyono. 2006. Statistika untuk Penelitian. Bandung: Alfabeta.

[33] Stiawan, Adi. 2010. Analisis Pengaruh Faktor Makroekonomi, Pangsa Pasar, dan Karakteristik Bank Terhadap Profitabilitas Bank Syariah (Studi Pada Bank Syariah Periode 2005-2008). Tesis Universitas Diponegoro.

[34] Thoby Mutis. Pengembangan Koperasi. Jakarta: Gramedia.

[35] Tohirin, Achmad. Implementasi Perbankan Islam -pengaruh sosioEkonomis dan

[36] perannya dalam pembangunan, jurnal ekonomi pembangunan : Yogyakarta, 2003.

[37] Ukas, Maman. 2009. Manajemen: Konsep, Prinsip dan Aplikasinya. Bandung: Agnini.

[38] Umar, Chapra Muhammad. 2001. Pandangan Islam terhadap Kesejahteraan, ekonom Muslim, Jakarta.

[39] Widoyono, Joko Lelono Bambang. 2011. Analisis Faktor-faktor yang mempengaruhi permintaan Pembiayaan Lembaga keuangan Syariah (studi kasus pada KOPERASI SYARIAH muamalah Baturetno Wonogiri). Tesis Universitas Negeri Sebelas Maret. 